№ 1 (4), 2021

УДК 621.3.052.31

В. Р. Левонюк

Львівський національний аграрний університет, кафедра електротехнічних систем, vitaliy_levoniuk@ukr.net

\title{
МАТЕМАТИЧНЕ МОДЕЛЮВАННЯ ПЕРЕХІДНИХ ПРОЦЕСІВ У ЛІНІЇ ЕЛЕКТРОПЕРЕДАЧІ НАДВИСОКОЇ НАПРУГИ В РЕЖИМАХ КОРОТКИХ ЗАМИКАНЬ
}

http://doi.org/10.23939/sepes2021.01.043

(C) Левонюк В. P., 2021

Проаналізовано публікації та з'ясовано, що сьогодні популярні два підходи до аналізу перехідних процесів у довгих лініях електропередач із розподіленими параметрами: на основі спрощених методів розв'язування рівняння довгої лінії або еквівалентації відомого рівняння довгої лінії коловими схемами заміщення. У разі застосування першого підходу автори не враховують погонних активних опору, фазної та міжфазної провідностей, обчислюючи зазвичай згадані процеси за відомими методами Д’Аламбера та «блукаючих хвиль». А другий підхід призводить до втрати фізичного змісту самого рівняння довгої лінії або потребус наявності крайових умов для згаданого рівняння, що не завжди можливо у разі моделювання перехідних процесів у складних електротехнічних системах пересилання енергії.

У цій праці аналіз перехідних процесів у довгій лінії електропередачі здійснено на основі диференціального рівняння довгої лінії другого порядку, що дає змогу уникнути наявності у рівнянні лінії двох змінних і тим самим полегшити реалізацію математичної моделі у вигляді програмного коду алгоритмічними мовами програмування. У статті побудовано математичну модель фрагмента електротехнічної системи пересилання енергії, ключовим елементом якого с довга лінія електропередачі, що об'єднує на паралельну роботу дві еквівалентовані електроенергетичні системи.

Наведено методику пошуку функцій вхідної та вихідної напруг на початку та у кінці довгої лінії, яка істотно розширяє сферу застосування розробленої математичної моделі лінії як автономного об'єкта у будь-яких загальних моделях електротехнічних систем пересилання енергії.

На підгрунті розробленої математичної моделі здійснено алгоритмізацію та комп'ютерну симуляцію перехідних процесів у лінії електропередачі під час однофазного та двофазного коротких замикань. Результати досліджень подано у вигляді рисунків, які проаналізовано. Усі викладені у роботі результати отримано з використанням числових методів.

Ключові слова: математичне моделювання; перехідні електромагнітні процеси; довга лінія електропередачі; розподілені параметри; однофазне коротке замикання; двофазне коротке замикання; надвисока напруга.

Постановка проблеми

Дослідження перехідних процесів в електротехнічних системах пересилання енергії (ЕТСПЕ) $\epsilon$ такою ж стандартною процедурою, як і маса інших, у будь-якій технічно-інженерній сфері. Це пов'язано з економією енергії, безпекою, надійністю тощо. 


\section{В. Р. Левонюк}

Якщо говорити про електроенергетику, то тут теж $є$ питання, відповіді на які дає аналіз перехідних процесів. Зокрема: що точніше нам відомі значення перенапруг та струмів короткого замикання (КЗ), які можуть виникати, то менше коштів можна витратити на ізоляційні матеріали та менші збитки від порушення нормального ведення народного господарства; що більше $\epsilon$ інформації про резонансні частоти в мережі, то точніше можна налаштовувати системи керування та ефективніше справлятися із впливами зовнішніх факторів; що детальніше вивчено поведінку обладнання у тих чи інших режимах, то простіше дотримуватися нормативних актів тощо. Сьогодні бурхливо розвивається ще одна сфера застосування розрахунків перехідних процесів - це обчислення у реальному часі. Дуже важливо, щоб необхідний часовий інтервал розрахунку був обчислений за такий самий період. Це застосовується для прототипування, тестування та налагодження пристроїв, які призначені для роботи з реальними системами керування та захисту (Smart Grid).

Інформацію щодо перехідних процесів можна отримати експериментально. Щоправда, це може зайняти дуже багато часу, потребувати значних матеріальних затрат i, що найголовніше, здійснення експериментів у енергосистемі, яка працює, - це серйозна справа. Якщо події розгортаються не згідно зі сценарієм, це може призвести до значних збитків. Тому сьогодні дослідження перехідних процесів у ЕТСПЕ здійснюють із використанням апарату математичного моделювання, особливо це актуально в системотвірних електричних мережах надвисокої напруги.

У коло наших наукових інтересів входять перехідні процеси у лініях електропередач (ЛЕП) надвисокої напруги. Довжина цих ліній вимірюється сотнями кілометрів, тому їх необхідно розглядати як системи 3 розподіленими параметрами, у яких відбуваються хвильові процеси, що 3 високим рівнем адекватності можна описати лише на основі польових підходів із залученням законів прикладної фізики. У нашому випадку для моделювання перехідних процесів у довгих ЛЕП використано рівняння довгої лінії другого порядку в частинних похідних. Розв'язання таких рівнянь потребує наявності крайових умов. Тому далі піде мова про способи ідентифікації крайових умов до рівняння довгої лінії, що дає змогу ефективно розв'язувати останнє та відтворювати перехідні електромагнітні процеси у довгих ЛЕП із високим ступенем адекватності.

\section{Аналіз останніх досліджень}

У науковій літературі є велика кількість робіт, які стосуються аналізу перехідних процесів у довгих ЛЕП. Розглянемо деякі з них, близькі до цієї праці.

У статті [1] запропоновано математичну модель фрагмента ЕТСПЕ, ключовим елементом якого $є$ довга ЛЕП, що живить трансформатор. Тут для моделювання перехідних електромагнітних процесів у лінії використано два рівняння довгої лінії першого порядку, для розв'язання яких застосовують крайові умови першого роду (умови Діріхле). У праці [2] теж розроблено математичну модель для обчислення перехідних процесів у трифазних ЛЕП. В основу цієї моделі покладено ті самі рівняння, що й у попередній праці, та крайові й початкові умови. Обидві моделі дають змогу відтворювати перехідні процеси у ЛЕП, але за наявності крайових умов.

У статті [3] для дослідження просторових розподілів струму в лінії, на основі колових схем заміщення, у програмному засобі "Fazonord-Kaчество" побудовано модель лінії з розподіленими параметрами. Ця модель дає змогу симулювати електричний контур із послідовного з'єднання $n$-ї кількості схем заміщення елементарних ділянок, а відтак відображати просторовий розподіл струму в лінії.

Ефективний числовий зворотний алгоритм перетворення Лапласа для аналізу перехідних процесів у ЛЕП з довільними розподілами напруги та струму в лінії запропоновано у праці [4]. Тут використано методологію перетворення Лапласа для знаходження напруг та струмів на краях лінії з урахуванням початкових умов. Фазні напруги та струми одержують як раціональні функції їх частоти.

Автори статті [5] пропонують для моделювання трифазних ЛЕП 3 розподіленими параметрами використовувати програмний комплекс $P S C A D$. Для відтворення процесів у ЛЕП 
Математичне моделювання перехідних процесів у лінї електропередачі надвисокої напруги...

програмний засіб використовує метод “блукаючих хвиль”. Згадану модель можна використовувати для моделювання перехідних процесів під час комутацій, КЗ та інших режимів роботи ЛЕП. Моделювання різноманітних режимів здійснюється із додатковим залучанням $R, L, C$ елементів.

У праці [6] для розв' язання рівняння довгої лінії використано крайові умови першого роду. За твердженням авторів, такий підхід доцільний, коли відомі крайові умови на початку і в кінці лінії (струми, напруги, заряди є заданими функціями), натомість у реальних задачах прикладної електротехніки згадані функціональні залежності крайових умов відомі не завжди, особливо коли це стосується аналізу складних елементів ЕТСПЕ, з’єднаних між собою довгою лінією. Оскільки ми аналізуємо складні електричні мережі, то крайові умови на початку та в кінці лінії (щодо функції напруги $u=u(x, t))$ невідомі, а це означає, що використання методики, яку запропонували автори, в нашому випадку недоцільне.

Також варто відзначити праці, аналіз перехідних процесів у яких здійснюється за допомогою програмного комплексу MatLab з використанням бібліотеки Simulink. Наприклад, у [7] побудовано імітаційну модель ЕТСПЕ, у якій для моделювання ЛЕП використано модель, вбудовану в згаданій бібліотеці.

Підсумовуючи сказане, можемо стверджувати, що математичному моделюванню перехідних процесів у довгих ЛЕП на польовому рівні приділено недостатньо уваги, натомість моделюванню згаданих процесів на основі спрощених підходів - достатньо. Однак ці підходи потребують чітко заданих крайових умов для рівнянь довгої лінії ([1], [2], [6]), обтяжені аналітичним інтегруванням ([4]) або ж використовують еквівалентні заміщення ([3]). Стосовно програмних комплексів PSCAD та MatLab/Simulink, то тут моделі ліній з розподіленими параметрами теж спрощені. Ці моделі враховують не всі розподілені параметри лінії [8], задля спрощення розрахунків за методами «блукаючих хвиль» та Д'Аламбера ([5], [7]), що може позначитися на адекватності отриманих результатів.

\section{Формування цілей статті}

Метою роботи $\epsilon$ покращення методів математичного моделювання перехідних електромагнітних процесів у довгих ЛЕП у нормальних та аварійних режимах роботи.

\section{Виклад основного матеріалу}

На рис. 1 наведено розрахункову схему заміщення прийнятого фрагмента ЕТСПЕ 750 кВ, яка з'єднує на паралельну роботу дві еквівалентовані електроенергетичні системи (ЕЕС). ЕЕС представлено фазними електрорушійними силами (ЕРС) $e_{C 1}{ }^{(A)}, e_{C 1}{ }^{(B)}, e_{C 1}{ }^{(C)}, e_{C 2}{ }^{(A)}, e_{C 2}{ }^{(B)}, e_{C 2}{ }^{(C)}$, індуктивностями $L_{C 1}{ }^{(A)}, L_{C 1}{ }^{(B)}, L_{C 1}{ }^{(C)}, L_{C 2}{ }^{(A)}, L_{C 2}{ }^{(B)}, L_{C 2}{ }^{(C)}$ та внутрішніми активними опорами $r_{C 1}{ }^{(A)}, r_{C 1}{ }^{(B)}$, $r_{C 1}{ }^{(C)}, r_{C 2}{ }^{(A)}, r_{C 2}{ }^{(B)}, r_{C 2}{ }^{(C)}$. ЛЕП подано у трифазному виконанні як лінію із розподіленими параметрами.

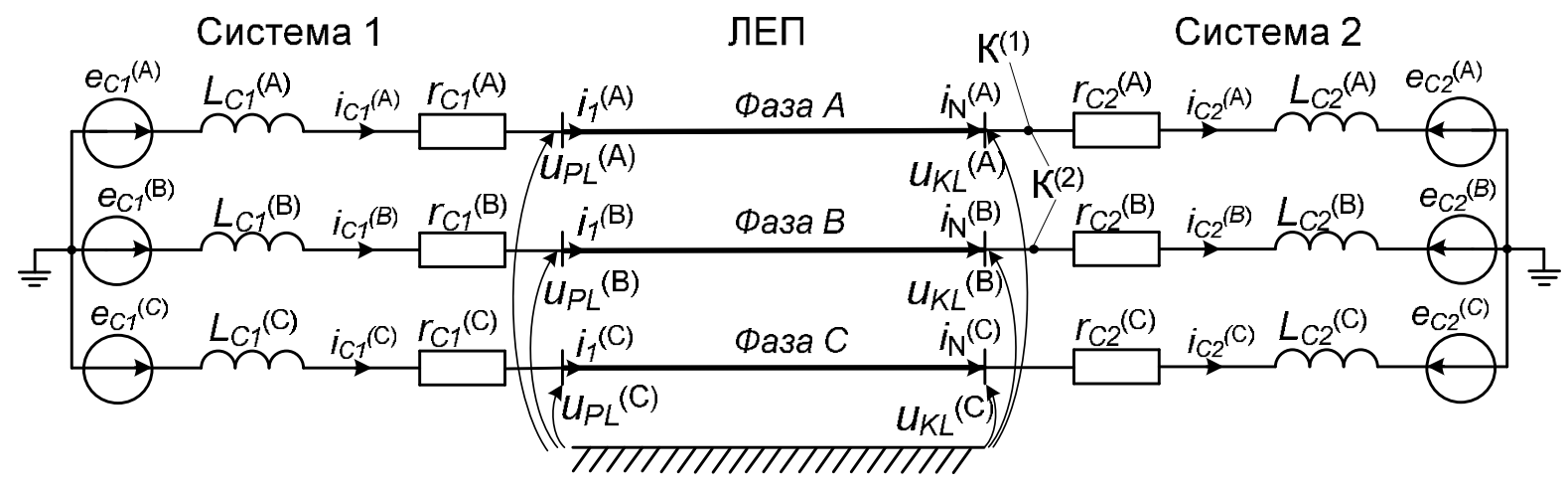

Рис. 1. Розрахункова схема замімення досліджуваного фрагмента ЕТСПЕ 


\section{В. Р. Левонюк}

Запишемо основні рівняння електромагнітного стану досліджуваного об'єкта на основі розрахункової схеми заміщення, наведеної на рис. 1, з використанням другого закону Кірхгофа та рівняння довгої лінії [9] у матрично-векторному вигляді:

$$
\begin{gathered}
\frac{d}{d t} \mathbf{i}_{C 1}=\mathbf{L}_{C 1}^{-1}\left(\mathbf{e}_{C 1}-\mathbf{r}_{C 1} \mathbf{i}_{C 1}-\mathbf{u}_{P L}\right), \quad \frac{d}{d t} \mathbf{i}_{C 2}=\mathbf{L}_{C 2}^{-1}\left(\mathbf{u}_{K L}-\mathbf{r}_{C 2} \mathbf{i}_{C 2}-\mathbf{e}_{C 2}\right) \\
\frac{\partial^{2} \mathbf{u}}{\partial t^{2}}=\left(\mathbf{C}_{0} \mathbf{L}_{0}\right)^{-1}\left(\frac{\partial^{2} \mathbf{u}}{\partial x^{2}}-\left(\mathbf{g}_{0} \mathbf{L}_{0}+\mathbf{C}_{0} \mathbf{r}_{0}\right) \frac{\partial \mathbf{u}}{\partial t}-\mathbf{g}_{0} \mathbf{r}_{0} \mathbf{u}\right)
\end{gathered}
$$

де

$$
\begin{aligned}
& \mathbf{r}_{C 1}=\operatorname{diag}\left(r_{C 1}^{(A)}, r_{C 1}^{(B)}, r_{C 1}^{(C)}\right), \mathbf{r}_{C 2}=\operatorname{diag}\left(r_{C 2}^{(A)}, r_{C 2}^{(B)}, r_{C 2}^{(C)}\right), \\
& \mathbf{L}_{C 1}=\operatorname{diag}\left(L_{C 1}^{(A)}, L_{C 1}^{(B)}, L_{C 1}^{(C)}\right), \mathbf{L}_{C 2}=\operatorname{diag}\left(L_{C 2}^{(A)}, L_{C 2}^{(B)}, L_{C 2}^{(C)}\right) ;
\end{aligned}
$$

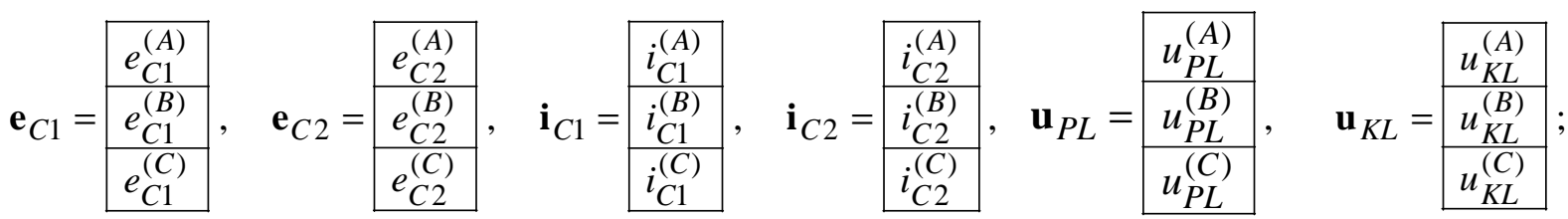

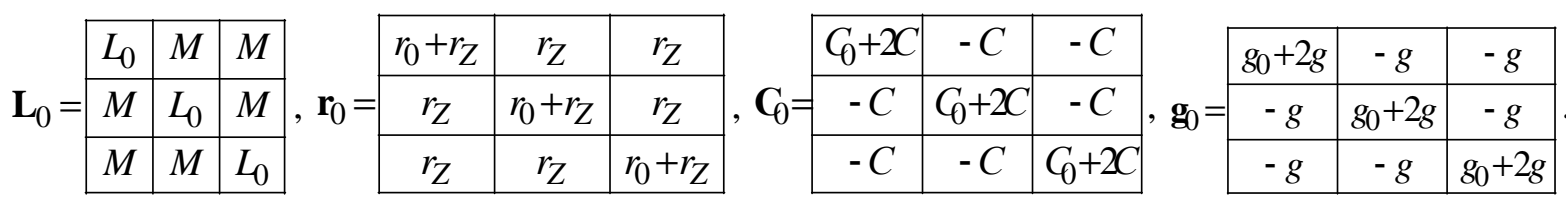

У векторах (4) $i_{C 1}{ }^{(A)}, i_{C 1}{ }^{(B)}, i_{C 1}{ }^{(C)}, i_{C 2}{ }^{(A)}, i_{C 2}{ }^{(B)}, i_{C 2}{ }^{(C)}$ - струми у фазних гілках EЕC 1 та 2, відповідно; $u_{P L}^{(A)}, u_{P L}{ }^{(B)}, u_{P L}{ }^{(C)}, u_{K L}{ }^{(A)}, u_{K L}^{(B)}, u_{K L}^{(C)}-$ фазні напруги на початку та в кінці лінії, відповідно. В матрицях (5) (для ідеально транспонованої лініі) $R_{0}, g_{0}, C_{0}, L_{0}-$ погонні опір, провідність, ємність та індуктивність фаз лінії, відповідно; $g, C$ - погонні міжфазні провідність та ємність, відповідно; $M-$ погонна взаємоіндуктивність; $r_{Z}-$ погонний опір землі. Втрати на корону враховуються активною фазною та міжфазною провідностями (матриця $\mathbf{g}_{0}$ ), які $\epsilon$ постійними (незмінними).

Для аналізу перехідних процесів у довгих ЛЕП ми використовуємо рівняння довгої лінії другого порядку (2), бо у нього входить лише одна змінна, натомість у рівняннях довгої лінії першого порядку буде дві змінні, що створює певні незручності під час організації програмних кодів для інтегрування згаданих рівнянь.

Основною проблемою під час розв'язання рівняння (2) є визначення крайових умов. Для нашого конкретного прикладу (рис. 1) до лінії з обох боків під'єднано еквівалентовані ЕЕС, тому крайові умови у нашому випадку невідомі з обох сторін лінії.

Для розв'язання рівняння (2) трифазної ЛЕП пропонуємо [10] використовувати крайові умови другого роду, зокрема рівняння

$$
-\frac{\partial \mathbf{u}}{\partial x}=\mathbf{L}_{0} \frac{\partial \mathbf{i}}{\partial t}+\mathbf{r}_{0} \mathbf{i}
$$

Рівняння (6) легко отримати на основі другого закону Кірхгофа для електричних кіл із розподіленими параметрами і за означенням [11] воно може бути крайовою умовою для рівняння (2). Застосування рівняння (6) як крайових умов для рівняння (2) дає змогу легко знаходити напруги у фіктивних вузлах лінії під час розв'язання рівняння (2) за методом прямих, що уможливлює відтворення не лише часових, а й просторових та часово-просторових розподілів напруг, а відтак i струмів вздовж лінії.

Дискретизуючи рівняння (2) та (6) за методом прямих, використовуючи поняття центральної похідної, отримаємо:

$$
\frac{d \mathbf{v}_{j}}{d t}=\left(\mathbf{C}_{0} \mathbf{L}_{0}\right)^{-1}\left(\frac{1}{(\Delta x)^{2}}\left(\mathbf{u}_{j-1}-2 \mathbf{u}_{j}+\mathbf{u}_{j+1}\right)-\left(\mathbf{g}_{0} \mathbf{L}_{0}+\mathbf{C}_{0} \mathbf{r}_{0}\right) \mathbf{v}_{j}-\mathbf{g}_{0} \mathbf{r}_{0} \mathbf{u}_{j}\right), \quad \frac{d \mathbf{u}_{j}}{d t}=\mathbf{v}_{j}, \quad j=1, \ldots, N
$$


Математичне моделювання перехідних процесів у лінї електропередачі надвисокої напруги...

$$
\frac{d \mathbf{i}_{j}}{d t}=\mathbf{L}_{0}{ }^{-1} \frac{1}{2 \Delta x}\left(\mathbf{u}_{j-1}-\mathbf{u}_{j+1}\right)-\mathbf{L}_{0}{ }^{-1} \mathbf{r}_{0} \mathbf{i}_{j}, \quad j=1, \ldots, N,
$$

де $\Delta x$ - крок дискретизації за методом прямих.

Записавши рівняння (7) та (8) для першого та останнього дискретних вузлів лінії $(j=1, j=N)$, бачимо, що у рівняння входитимуть невідомі напруги у фіктивних вузлах $\mathbf{u}_{0}$ та $\mathbf{u}_{N+1}$, що

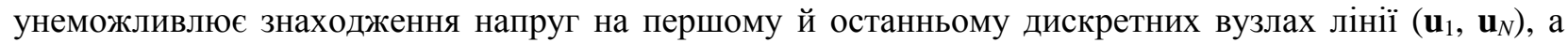
також струмів у першій та останній дискретних гілках лінії $\left(\mathbf{i}_{1}, \mathbf{i}_{N}\right)$. Викладемо процедури знаходження напруг у фіктивних вузлах на початку та в кінці лінії.

Для “сумісного поєднання" рівняння довгої лінії (польового підходу до аналізу перехідних процесів у лінії) та схем заміщення еквівалентованих ЕЕС (колового підходу) пропонуємо розглянути першу та останню елементарні дискретні ділянки лінії на основі прямої $Г$-схеми заміщення ЛЕП. Тоді, наприклад, для фази $A$ матимемо схему, наведену на рис. 2.

На рис. 2 подано схему заміщення 3'єднання еквівалентованої ЕЕС 1 та першої дискретної ділянки лінії у вузлі № 1 (подано лише для фази $A$ ). У цьому випадку, внаслідок використання прямої $\Gamma$-схеми заміщення елементарної ділянки лінії напруга на початку лінії тотожно дорівнює напрузі першого дискретного вузла лінії ( $\left.\mathbf{u}_{P L} \equiv \mathbf{u}_{1}\right)$.

За першим законом Кірхгофа, для всієї системи, з урахуванням прикладу, наведеного на рис. 2, запишемо рівняння у матрично-

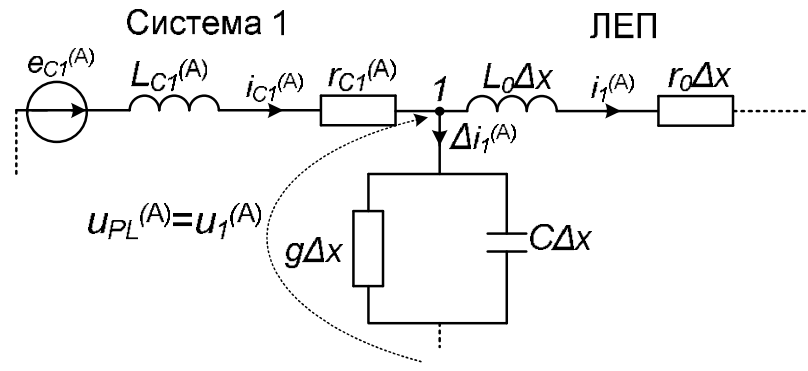

Рис. 2. Схема заміщення для пошуку напруги у фіктивному вузлі на початку лініі векторному вигляді

$$
\begin{gathered}
\mathbf{i}_{C 1}-\mathbf{i}_{1}-\Delta \mathbf{i}=0, \quad \Delta \mathbf{i}=\operatorname{colon}\left(\Delta i^{(A)}, \Delta i^{(B)}, \Delta i^{(C)}\right), \\
\Delta i^{(A)}=\Delta i^{(A B)}+\Delta i^{(A C)}+\Delta i^{(A Z)}, \Delta i^{(B)}=\Delta i^{(A B)}+\Delta i^{(B C)}+\Delta i^{(B Z)}, \Delta i^{(C)}=\Delta i^{(C A)}+\Delta i^{(B C)}+\Delta i^{(C Z),}
\end{gathered}
$$

де $\Delta i^{(m, n)}, \Delta i^{(m, Z)}-$ струми витоку між фазами $(m, n-$ фази лінії, $m \neq n)$ та фазою і землею, відповідно.

На основі положень теоретичної електротехніки струми витоку $\Delta \mathbf{i}$ можемо знайти так

$$
\Delta \mathbf{i}=\Delta x \mathbf{C}_{0} \frac{d \mathbf{u}_{1}}{d t}+\Delta x \mathbf{g}_{0} \mathbf{u}_{1} .
$$

Далі продиференціюємо перше рівняння 3 (9) та вираз (11) за часом, 3 урахуванням початкових умов [12], тоді отримаємо

$$
\frac{d \mathbf{i}_{C 1}}{d t}-\frac{d \mathbf{i}_{1}}{d t}-\frac{d \Delta \mathbf{i}}{d t}=0, \quad \frac{d \Delta \mathbf{i}}{d t}=\Delta x \mathbf{C}_{0} \frac{d \mathbf{v}_{1}}{d t}+\Delta x \mathbf{g}_{0} \mathbf{v}_{1} .
$$

Підставимо у перше рівняння 3 (12) перше рівняння з (1), рівняння (8), записане для першої дискретної гілки лінії $(j=1)$, та друге рівняння з (12). Отримаємо

$$
\mathbf{L}_{C 1}^{-1}\left(\mathbf{e}_{C 1}-\mathbf{r}_{C 1} \mathbf{i}_{C 1}-\mathbf{u}_{P L}\right)-\left(\mathbf{L}_{0}^{-1} \frac{1}{2 \Delta x}\left(\mathbf{u}_{0}-\mathbf{u}_{2}\right)-\mathbf{L}_{0}^{-1} \mathbf{r}_{0} \mathbf{i}_{1}\right)-\left(\Delta x \mathbf{C}_{0} \frac{d \mathbf{v}_{1}}{d t}+\Delta x \mathbf{g}_{0} \mathbf{v}_{1}\right)=0 .
$$

Тепер, підставивши у вираз (13) перше рівняння з (7), яке записане для першого дискретного вузла лінії $(j=1)$, та виразивши звідти функцію напруги фіктивного вузла $\mathbf{u}_{0}$ (враховуючи, що $\left.\mathbf{u}_{P L} \equiv \mathbf{u}_{1}\right)$, отримаємо:

$$
\begin{gathered}
\mathbf{u}_{0}=\frac{2 \Delta x}{3} \mathbf{L}_{0}\left[\left(\mathbf{L}_{0}^{-1}\left(\frac{2}{\Delta x}+\Delta x \mathbf{g}_{0} \mathbf{r}_{0}\right)-\mathbf{L}_{C 1}^{-1}\right) \mathbf{u}_{1}-\frac{1}{2 \Delta x} \mathbf{L}_{0}^{-1} \mathbf{u}_{2}+\right. \\
\left.+\Delta x\left(\mathbf{L}_{0}^{-1}\left(\mathbf{g}_{0} \mathbf{L}_{0}+\mathbf{C}_{0} \mathbf{r}_{0}\right)-\mathbf{g}_{0}\right) \mathbf{v}_{1}+\mathbf{L}_{0}^{-1} \mathbf{r}_{0} \mathbf{i}_{1}+\mathbf{L}_{C 1}^{-1}\left[\mathbf{e}_{C 1}-\mathbf{r}_{C 1} \mathbf{i}_{C 1}\right]\right] .
\end{gathered}
$$




\section{В. Р. Левонюк}

Вираз (14) описує функцію напруги фіктивного вузла на початку лінії. Далі наведемо деякі елементи процедури знаходження функції напруги фіктивного вузла у кінці лінії.

Методика пошуку напруги $\mathbf{u}_{N+1}$ описана та апробована у праці [10] з урахуванням автономності математичної моделі лінії, що дало змогу, вводячи у згадану модель параметр "вихідна напруга" (напруга в кінці лінії $\mathbf{u}_{K L}=\left.\mathbf{u}\right|_{x=l}\left(\mathbf{u}_{N} \neq\left.\mathbf{u}\right|_{x=l}\right)$, див. рис. 3), уникати зміни математичної моделі лінії під

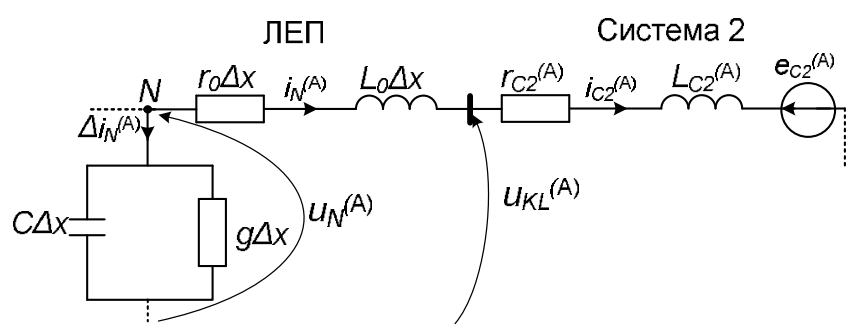

Рис. 3. Схема заміщення для пошуку напруги у фіктивному вузлі в кінці лініі час моделювання ЕТСПЕ різних конфігурацій з'єднань лінії з іншими елементами.

На рис. 3 подано схему заміщення 3'єднання останньої дискретної ділянки лінії та еквівалентованої ЕЕС 2 (лише для фази $A$ ).

Функція фіктивної напруги у кінці лінії має вигляд [10]

$$
\mathbf{u}_{N+1}=\mathbf{u}_{N-1}+2\left(\mathbf{u}_{K L}-\mathbf{u}_{N}\right) .
$$

Наведемо процедуру пошуку напруги $\mathbf{u}_{K L}$, яка входить у вираз (15). Для останнього дискретного контура лінії (рис. 3) запишемо рівняння за другим законом Кірхгофа у матричновекторній формі:

$$
\frac{d \mathbf{i}_{N}}{d t}=\left[\Delta x \mathbf{L}_{0}\right]^{-1}\left(\mathbf{u}_{N}-\Delta x \mathbf{R}_{0} \mathbf{i}_{N}-\mathbf{u}_{K L}\right) .
$$

Струм $\mathbf{i}_{N}$ тотожно дорівнює струму $\mathbf{i}_{C 2}$ (див. рис. 3 ), отже, з урахуванням початкових умов, можемо записати (прирівнюємо похідні струмів) [12]:

$$
\mathbf{i}_{N} \equiv \mathbf{i}_{C 2} \Rightarrow \frac{d}{d t} \mathbf{i}_{N} \equiv \frac{d}{d t} \mathbf{i}_{C 2} .
$$

Підставивши у (17) друге рівняння з (1) та рівняння (16), отримаємо:

$$
\left[\Delta x \mathbf{L}_{0}\right]^{-1}\left(\mathbf{u}_{N}-\Delta x \mathbf{R}_{0} \mathbf{i}_{N}-\mathbf{u}_{K L}\right)=\mathbf{L}_{C 2}^{-1}\left(\mathbf{u}_{K L}-\mathbf{r}_{C 2} \mathbf{i}_{C 2}-\mathbf{e}_{C 2}\right)
$$

Виразивши з (18) функцію напруги $\mathbf{u}_{K L}$, одержимо:

$$
\mathbf{u}_{K L}=\left[\mathbf{L}_{C 2}^{-1}+\left[\Delta x \mathbf{L}_{0}\right]^{-1}\right]^{-1}\left[\left[\Delta x \mathbf{L}_{0}\right]^{-1}\left(\mathbf{u}_{N}-\left[\Delta x \mathbf{R}_{0}\right] \mathbf{i}_{N}\right)+\mathbf{L}_{C 2}^{-1}\left(\mathbf{r}_{C 2} \mathbf{i}_{C 2}+\mathbf{e}_{C 2}\right)\right] .
$$

Сумісному інтегруванню підлягає така система диференціальних рівнянь: (1), (7), (8) 3 урахуванням (3)-(5), (10), (14), (15) та (19).

Результати комп'ютерної симуляції. Виконання комп'ютерної симуляції перехідних процесів у ЕТСПЕ (рис. 1) відбувалося на основі створеного нами програмного коду алгоритмічною мовою Visual Fortran на підгрунті розробленої математичної моделі. Під час симуляції досліджували перехідні процеси під час виникнення однофазного К3 (ОКЗ) 3 подальшим переходом у двофазне КЗ у кінці лінії електропередачі (точка $K$, див. рис. 1 )).

Комп'ютерна симуляція здійснювалася у такій послідовності. У момент часу $t=0 \mathrm{c}$ відбулося увімкнення ЛЕП на паралельну роботу еквівалентних ЕЕС 1 та 2. Після виходу на нормальний усталений режим, у момент часу $t_{\kappa 3}{ }^{(1)}=0,36 \mathrm{c}$, у кінці ЛЕП (на шинах системи 2) імітувалося ОКЗ $K^{(1)}\left(К 3\right.$ фази $A$ на землю, див. рис. 1), через $50 \mathrm{мc}$ у момент часу $t_{K 3}{ }^{(2)}=0,41 \mathrm{c}$ однофазне КЗ перейшло у двофазне КЗ $K^{(2)}$ (КЗ між фазами $A$ та $B$ на землю, див. рис. 1$)$.

Під час комп'ютерної симуляції роботу протиаварійної автоматики та релейного захисту лінії не моделювали, оскільки симуляція комутаційних процесів при КЗ не є завданням цієї праці.

Прийняті нижче параметри елементів схеми заміщення (рис. 1) відповідають параметрам фрагмента реальної ЕТСПЕ 750 кВ із ЛЕП довжиною 360,5 км, яка 3'єднує ПС “Західноукраїнська" з ПС “Вінницька". Параметри розподіленої симетричної ЛЕП такі: $R_{0}=1,9 \cdot 10^{-5} \mathrm{OM} / \mathrm{M}$, $L_{0}==1,665 \cdot 10^{-6} \Gamma \mathrm{H} / \mathrm{M}, \quad C_{0}=1,0131 \cdot 10^{-11} \Phi / \mathrm{M}, \quad g_{0}=3,25 \cdot 10^{-11} \mathrm{CM} / \mathrm{M}, \quad C=1,0122 \cdot 10^{-12} \Phi / \mathrm{M}$, $g=3,25 \cdot 10^{-13} \mathrm{CM} / \mathrm{M}, R_{\mathrm{Z}}=5 \cdot 10^{-5} \mathrm{Oм} / \mathrm{M}, M_{0}=7,41 \cdot 10^{-7} \Gamma / \mathrm{M}$. Параметри еквівалентованих ЕЕС: 
Математичне моделювання перехідних процесів у лінї електропередачі надвисокої напруги...

$r_{C 1}{ }^{(A)}=r_{C 1}{ }^{(B)}==r_{C 1}{ }^{(C)}=2,032$ Ом, $\quad r_{C 2}{ }^{(A)}=r_{C 2}{ }^{(B)}=r_{C 2}{ }^{(C)}=2,41 \quad$ OM, $\quad L_{C 1}{ }^{(A)}=L_{C 1}{ }^{(B)}=L_{C 1}{ }^{(C)}=0,161 \quad$ Oм, $L_{C 2}{ }^{(A)}=L_{C 2}{ }^{(B)}==L_{C 2}{ }^{(C)}=0,141$ Ом. Комп'ютерну симуляцію здійснено за таких параметрів режиму: $e_{C 1}^{(A)}=593,5 \sin \left(314 t+20,5^{\circ}\right) \mathrm{\kappa B}, e_{C 1}^{(B)}=593,5 \sin \left(314 t-99,5^{\circ}\right) \mathrm{\kappa B}, e_{C 1}{ }^{(C)}=593,5 \sin \left(314 t+140,5^{\circ}\right) \kappa \mathrm{B}$, $e_{C 2}{ }^{(A)}=598,0 \sin \left(314 t+4,1^{\circ}\right) \mathrm{\kappa B}, e_{C 2}{ }^{(B)}=598,0 \sin \left(314 t-115,9^{\circ}\right) \mathrm{\kappa B}, e_{C 2}{ }^{(C)}=598,0 \sin \left(314 t+124,1^{\circ}\right) \mathrm{\kappa B}$. Крок просторової дискретизації диференціальних рівнянь 3 частинними похідними за методом прямих дорівнює: $\Delta x=l / 20==360,5 / 20=18$ км. Звичайні диференціальні рівняння інтегрувалися числовим методом Гіра з кроком $\Delta t=27$ мкс.

Деякі характерні результати досліджень режимів КЗ у точці $K$ в кінці лінії (див. рис. 1) подано на рис. 4-6, де функціональні часові розподіли струмів та напруг, позначені жовтими лініями, стосуються фази $A$, зеленими - фази $B$, а червоними - фази $C$.

Аналізуючи одержані часові розподіли струмів посередині ЛЕП (рис. 4), бачимо, що після виходу в усталений режим їх амплітуди дорівнюють 1,09 кА. Після виникнення ОКЗ на фазі $A$ $\left(t_{\kappa 3}{ }^{(1)}=0,36\right.$ c) iï ударний струм сягнув 9,08 кА, фази $B-2,9$ кА, а фази $C-4,94$ кА. Варто зазначити, що після виникнення згаданого ОКЗ струми фаз $B$ та $C$ посередині лінії почали збігатись за фазою й одночасно бути у протифазі до фази $A$. Через 50 мс відбувся перехід від ОКЗ на фазі $A$ до двофазного КЗ на землю $\left(\left(t_{K 3}{ }^{(2)}=0,41 \mathrm{c}\right)\right.$, К3 фази $A$ та $\left.B\right)$. Бачимо, що виникнення додаткового К3 на фазі $B$ не вплинуло на амплітуду струму фази $A$, вона, як і раніше, продовжила виходити в усталений режим КЗ (амплітуда струму фази $A$ усталеного режиму КЗ становить 5,62 кА). Щодо фази $B$, то після виникнення К3 на цій фазі їі ударний струм сягнув 4,73 кА, а амплітуда струму фази $B$ усталеного режиму КЗ становить 4,98 кА. Амплітуда струму фази $C$, навпаки, зменшилася, в усталеному режимі КЗ вона становить 2,45 кА. Щодо зсуву фаз, то після виникнення другого КЗ струми фаз $B$ та $C$ перестали збігатись за фазою.

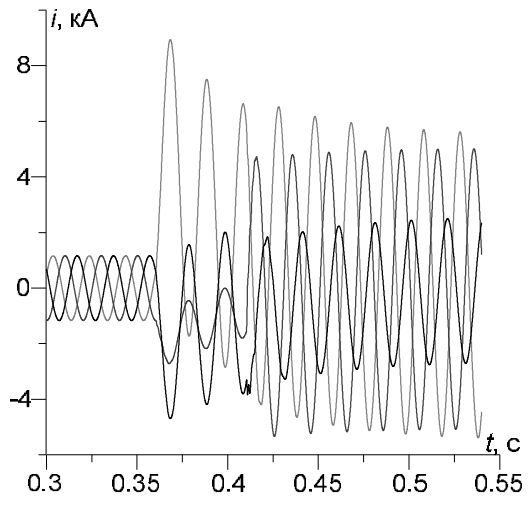

Рис. 4. Перехідні прочеси фазних струмів посередині лініі

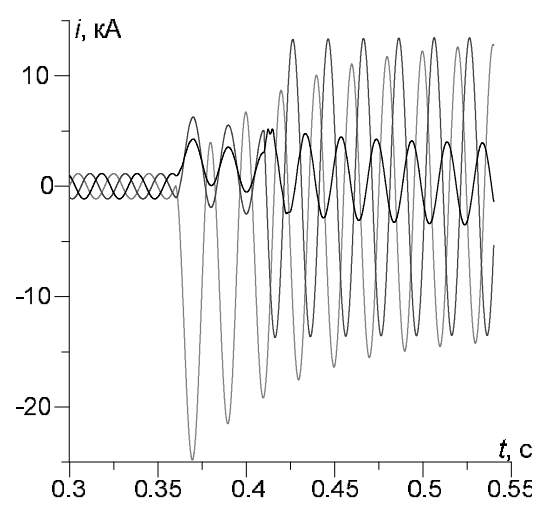

Рис. 5. Перехідні прочеси фазних струмів системи 2

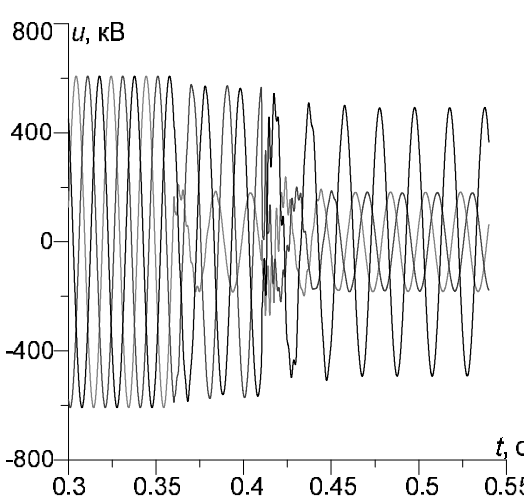

Рис. 6. Перехідні прочеси фазних напруг у лінії за 108 км до місия КЗ

На рис. 5 бачимо, що амплітуди струмів фаз системи 2 у нормальному усталеному режимі становлять 0,89 кА. Після виникнення ОКЗ ударний струм фази $A$ сягнув -25 кА, фази $B-6,18$ кА, а фази $C-4,11$ кА. Виникнення другого КЗ практично не вплинуло на струм фази $A$, а ударні струми фаз $B$ та $C$ сягнули 14,38 кА та 5,03 кА, відповідно. Амплітуди струмів фаз $A, B$ та $C$ усталеного режиму КЗ становлять 12,95 кА, 14,19 кА та 3,75 кА, відповідно. Щодо зсуву фаз, то тут картина повністю ідентична з рис. 4 , як під час першого, так і другого КЗ.

На рис. 6 подано перехідні процеси фазних напруг у лінії за 108 км від місця КЗ. У нормальному усталеному режимі амплітудні значення фазних напруг становлять 607 кВ. Після виникнення ОКЗ амплітудне значення напруги фази $A$ зменшилося до $181 \mathrm{\kappa B}$, фази $B$ до $572 \mathrm{\kappa B}$, а фази $C$ - до 560 кВ. Після двофазного КЗ амплітудні значення напруг фаз $A, B$ та $C$ становили 184 кВ, 181 кВ та 494 кВ, відповідно. Варто зазначити, що як за першого, так і за другого КЗ у функціях напруг наявні своєрідні перехідні процеси. 


\section{В. Р. Левонюк}

\section{Висновки}

1. Застосування польових підходів до моделювання довгих ЛЕП (рівняння довгої лінії), на противагу до широко застосовуваних у літературі колових схем заміщення та спрощених підходів, дає змогу з високим ступенем адекватності ураховувати хвильові процеси у згаданих лініях.

2. Для розв'язання диференціального рівняння довгої лінії з розподіленими параметрами використано крайові умови другого роду (умови Неймана), що дає змогу уникнути часоплинної та складної процедур пошуку невідомих функцій напруг на початку та в кінці лінії, тобто пошуку крайових умов першого роду (умов Діріхле).

3. Запропонована у статті методика пошуку функцій вхідної та вихідної напруг на початку та кінці довгої лінії істотно розширює область застосування моделі лінії як автономного об'єкта у будьяких загальних моделях ЕТСПЕ.

\section{Список літератури}

1. Kotlan V., Benesova Z. Overvoltage Propagation from Transmission Line into Transformer Winding. Power engineering and electricalengineering. 2015. Vol. 13. № 5. P. 478-483. doi: 10.15598/aeee.v13i5.1421.

2. Лободзинський В. Ю., Чибеліс В. І. Математична модель трифазної лінії з розподіленими параметрами при електромагнітних перехідних проиесах. Вісник КНУТД. 2018. № 4 (124). С. 96-102.

3. Закарюкин В. П., Крюков А. В. Токораспределение в проводах высоковольтных линий электропередачи. Известия выстих учебных заведений. Проблемы енергетики. 2010. C. 59-64. https://cyberleninka.ru/ article/n/modelirovanie-tokoraspredeleniya-v-mnogoprovodnyh-liniyah-elektroperedachi.

4. Jung-Chien Li. Transient analysis of three-phase transmission lines with initial voltage and current distributions. Electric Power Systems Research. 1995. Vol. 35. Issue 3. P. 177-186.

5. Smolarczyk A., Chmielak W. Program PSCAD/EMTDC jako wygodne narzedzie do modelowania linii napowietrznych. Prace instytutu elektrotechniki. 2016. № 272. S. 31-48. https://www.sciencedirect.com/science/ article/ abs/pii/0378779695010068.

6. Кириленко О. В., Сегеда М. С., Буткевич О. Ф., Мазур Т. А. Математичне моделювання в електроенергетиці. Львів: Львівська політехніка, 2010. 608 с.

7. Pruski P., Paszek S. Analysis of transient waveforms in a power system at asymmetrical short-circuits. Przeglad elektrotechniczny. 2020. № 2. S. 26-29. doi:10.15199/48.2020.02.05.

8. Hermann W. Dommel. Digital Computer Solution of Electromagnetic Transients in Single- and Multiphase Networks. IEEE Transactions On Power Apparatus And Systems. 1969. P. 388-399. https://ieeexplore.ieee.org/ document/4073845.

9. Шимони К. Теоретическая електротехника. Москва: Мир, 1956. 773 с.

10. Левонюк В. Р. Математичне моделювання перехідних процесів у трифазній лінії електропередачі в режимі двофазного короткого замикання. Електроенергетичні та електромеханічні системи. 2020. Вип. 2, № 1s. C. 9-17. http://science.lpnu.ua/sites/default/files/journal-paper/2020/nov/22305/200864maket1-11-19.pdf.

11. Боглаев Ю. П. Вычислительная математика и программирование. Москва: Высшая школа, 1990. $544 c$

12. Чабан А. В. Приниип Гамільтона-Остроградського в електромеханічних системах. Львів: В-во Тараса Сороки, 2015. 488 c.

\section{References}

1. Kotlan V., Benesova Z. Overvoltage Propagation from Transmission Line into Transformer Winding. Power engineering and electricalengineering. 2015. Vol. 13. No. 5. P. 478-483. doi: 10.15598/aeee.v13i5.1421.

2. Lobodzinsky V. Yu., Chibelis VI Mathematical model of a three-phase line with distributed parameters in electromagnetic transients. BULLETIN OF KNUTD. 2018. No. 4 (124). C. 96-102. doi: 10.30857/18136796.2018.4.10.

3. Zakaryukin V. P., Kryukov A. V. Current distribution in wires of high-voltage power lines. News of higher educational institutions. Energy problems. 2010. P. 59-64. (Ukr). https://cyberleninka.ru/article/n/modelirovanietokoraspredeleniya-v-mnogoprovodnyh-liniyah-elektroperedachi.

4. Jung-Chien Li. Transient analysis of three-phase transmission lines with initial voltage and current distributions. Electric Power Systems Research. 1995. Vol. 35. Issue 3. P. 177-186. 
Математичне моделювання перехідних процесів у лінї електропередачі надвисокої напруги...

5. Smolarczyk A., Chmielak W. PSCAD / EMTDC software as a convenient tool for modeling overhead lines. Works of the electrotechnical institute. 2016. No. 272. P. 31-48. (Pol). https://www.sciencedirect.com/science/article/ abs/pii/0378779695010068.

6. Kirilenko O. B., Szegeda M. S., Butkevich O.F., Mazur T. A. Mathematical modeling in electric power industry. Lviv: Lviv Polytechnic University Island, 2010. 608 p. (Ukr).

7. Pruski P., Paszek S. Analysis of transient waveforms in a power system at asymmetrical short-circuits. Przeglad elektrotechniczny. 2020. No. 2. P. 26 - 29. doi:10.15199/48.2020.02.05.

8. Hermann W. Dommel. Digital Computer Solution of Electromagnetic Transients in Single-and Multiphase Networks. IEEE Transactions On Power Apparatus And Systems. 1969. P. 388-399. https://ieeexplore.ieee.org/ document/4073845.

9. Shimoni K. Theoretical electrical engineering. Moscow: Mir, 1956. 773 p. (Rus).

10. Levoniuk V. Mathematical modeling of transients processes in thre-phase transmission line in two-phase short circuit mode. Electrical power and electromechanical systems. 2020. Vol. 2. P. 9-17. (Ukr). http://science. lpnu.ua/sites/default/files/journal-paper/2020/nov/22305/200864maket1-11-19.pdf.

11. Boglaev Yu. P. Computational Mathematics and Programming. Moscow: High School, 1990. 544 p. (Rus).

12. Chaban A. V. The Hamilton-Ostrogradsky principle in electromechanical systems. Lviv: Taras Soroka Island, 2015. $488 \mathrm{p}$. (Ukr).

V. Levoniuk

Lviv National Agrarian University,

Department of Electrical Systems, vitaliy_levoniuk@ukr.net

\section{MATHEMATICAL MODELING OF TRANSITION PROCESSES IN THE HIGH VOLTAGE TRANSMISSION LINE IN SHORT CIRCUIT MODES}

(C) Levoniuk V., 2021

The article analyzes the publications, which shows that two approaches to the analysis of transients in long power lines with distributed parameters are popular today: based on simplified methods of solving the equation of a long line, or equivalent to the known equation of a long line by circuit substitution schemes. In applying the first approach, the authors do not take into account the running resistance, phase and interphase conductivities, calculating the usually mentioned processes by the known methods of D'Alembert and "wandering waves". The application of the second approach leads to the loss of the physical meaning of the equation of the long line, or requires the presence of boundary conditions to the mentioned equation, which is not always possible when modeling transients in complex electrical energy transfer systems.

In the present work, the analysis of transients in a long power line is based on the differential equation of a long line of the second order, which avoids the presence of two variables in the line equation and thus facilitate the implementation of the mathematical model in the form of program code in algorithmic programming languages. Thus, the article builds a mathematical model of a fragment of an electrical power transmission system, the key element of which is a long power line that combines two equivalent power systems for parallel operation.

The article presents a method for finding the functions of input and output voltages at the beginning and end of a long line, which significantly expands the scope of the developed mathematical model of the line as a stand-alone object in any general models of electrical power transmission systems.

Based on the developed mathematical model, algorithmization and computer simulation of transients in the power line during single-phase and two-phase short circuits were performed. The research results are presented in the form of figures that are analyzed. All the results presented in this paper were obtained using numerical methods.

Key words: mathematical modeling; transient electromagnetic processes; long power line; distributed parameters; single-phase short circuit; two-phase short circuit; ultrahigh voltage. 